\title{
INSIGHTS OF ELITE CUSTOMER PERSPECTIVE TOWARDS AUTOMATIC TELLER MACHINE IN DELHI NCR
}

\author{
Dr Leena Jenefa \\ Associate Professor, Department of Management Studies \\ Tecnia Institute of Advanced Studies, Delhi-India \\ Rahul Tripathi \\ Assistant Professor, Department of Management Studies \\ Tecnia Institute of Advanced Studies, Delhi-India
}

\begin{abstract}
The banking industry faced lot of challenges in its operations. Lot of progress were made in banking sector especially in electronic banking. The ATM is an electronic device with electronic digital access to the customer accounts in the banks. It was installed and maintained by Commercial Banks. Customer satisfaction towards banking sector plays an important role in today's business context. Schiffman (2004) the customer satisfaction as perception of individuals into products and services offered by a business with their expectations. The Customer Satisfaction towards services oriented business will impact directly to the success of firms in the long run. This study was conducted to critically examine the customers' level of satisfaction on ATM services offered by the commercial banks in Delhi. Primary data were collected from 150 respondents by applying proportionate convenience sampling technique. Secondary data were collected from various books, journals and magazines. Various Hypotheses were framed and tested for this research. Chi square test and Percentage technique were used to analyze the satisfaction of customers towards the ATM Services. The data was analyzed using SPSS 25.
\end{abstract}

Keywords: Customer Satisfaction, Commercial Bank, Automatic Teller Machine

\section{INTRODUCTION}

The banking industry faced lot of challenges in its operations. Lot of progress were made in banking sector especially in electronic banking. The ATM is an electronic device with electronic digital access to the customer accounts in the banks. It was installed and maintained by Commercial Banks.

The concept of automated teller machine (ATM) has been developed throughout the world and plays an important role for daily day today's business. The automatic teller machine is commonly used by commercial bank for customer financial transactions like withdrawing cash, depositing cash, transfer of fund to another, payment, cash balance in the account, cheque book requests and etc. It is an unattended device usually located on or off the banks premises.

The customer satisfaction depends on the performance of the product relative to a customer expectation. The customer's satisfactions were measured by usage of ATM services, education of the customer and gender of the customer.

\section{REVIEW OF LITERATURE}

Asif-Khan (2010), in his research he mentioned that customer convenience, efficient operation, security of using ATM services, reliability and responsiveness towards complaint have a significant dimension on ATM service quality.

Motwani D et al. (2012) in their study highlights the awareness level and satisfaction of customers regarding ATM services. Various statistical tools have been used like chi- square test, ANOVA, weighted mean to test the hypothesis and revealed that awareness level is affected by demographic profile of customers. 
L.Jenefa (2018), Banks are important in every country because of their crucial role in supporting economic development through efficient financial services. Highly satisfied customer can be called delighted customer.

Liswaniso et al. (2018), study intended to determine the various services can be accessed at the same time using internet banking. The study concluded that the internet banking in African Countries has not reached to required level yet.

\section{RESEARCH METHODOLOGY}

The methodology of the study is done through exploratory design. The researcher used Primary and secondary data for analysis. The primary data was collected through well-structured questionnaires .The data were collected from students, business man, professionals, working personal, house wife. Primary data were collected from 150 respondents by applying proportionate convenience sampling technique. The secondary data Secondary data were collected from various books, journals and magazines.

\section{ANALYSIS AND INTERPRETATION}

\section{A. Demographic Factors}

Table 1: Gender

\begin{tabular}{|c|c|c|c|c|}
\hline \multicolumn{2}{|c|}{ Gender } & Frequency & Percent & $\begin{array}{l}\text { Cumulative } \\
\text { Percent }\end{array}$ \\
\hline Valid & Male & 79 & 52.7 & 52.7 \\
& & & & \\
\cline { 2 - 5 } & Female & $\mathbf{7 1}$ & $\mathbf{4 7 . 3}$ & $\mathbf{1 0 0 . 0}$ \\
\cline { 2 - 5 } & Total & 150 & 100.0 & \\
\hline
\end{tabular}

Source : Primary data.

From the table 1, majority $52.7 \%$ of the respondents belongs to male and $47.3 \%$ of the respondents belongs to female.

Table 2: Age

\begin{tabular}{|l|c|c|c|c|}
\hline \multicolumn{2}{|l|}{ Age } & Frequency & Percent & $\begin{array}{l}\text { Cumulative } \\
\text { Percent }\end{array}$ \\
\hline Valid & $\mathbf{0 - 2 0}$ & 31 & 20.7 & 20.7 \\
\cline { 2 - 5 } & $21-30$ & 47 & 31.3 & 52.0 \\
\cline { 2 - 5 } & $31-40$ & 37 & 24.7 & 76.7 \\
\cline { 2 - 5 } & $41-50$ & 24 & 16.0 & 92.7 \\
\cline { 2 - 5 } & $\begin{array}{c}51 \text { and } \\
\text { above }\end{array}$ & 11 & 7.3 & 100.0 \\
\cline { 2 - 5 } & Total & 150 & 100.0 & \\
\hline
\end{tabular}

Source : Primary data

From the table 2, majority $31.3 \%$ of the respondents belongs to the age 21-30. 24\% of the respondent belongs to the age $31-40.20 .7 \%$ of the respondent belongs to age $0-20.16 \%$ of the respondents belongs to the age $41-50$ and $7.3 \%$ of the respondents belongs to the age 51-above.

Table 3: Education

\begin{tabular}{|c|c|c|c|c|}
\hline \multicolumn{2}{|c|}{ Education } & $\begin{array}{c}\text { Frequenc } \\
\text { y }\end{array}$ & $\begin{array}{c}\text { Percen } \\
\text { t }\end{array}$ & $\begin{array}{c}\text { Cumulativ } \\
\text { e Percent }\end{array}$ \\
\hline $\begin{array}{c}\text { Vali } \\
\text { d }\end{array}$ & 10th Pass & 16 & 10.7 & 10.7 \\
\cline { 2 - 5 } & 12th Pass & 46 & 30.7 & 41.3 \\
\cline { 2 - 5 } & Graduate & 45 & 30.0 & 71.3 \\
\cline { 2 - 5 } & $\begin{array}{c}\text { Post Graduate } \\
\text { and Above }\end{array}$ & 43 & 28.7 & 100.0 \\
\cline { 2 - 5 } & Total & 150 & 100.0 & \\
\hline
\end{tabular}

Source : Primary data

From the table 3, majority $30.7 \%$ of the respondents passed $12^{\text {th }}$ standard. $30 \%$ of the respondent completed graduate. $28.7 \%$ of the respondent completed post graduate $.10 .7 \%$ of the respondents was passed the tenth standard.

\section{B. Problem faced by the Customer}

Table 4: Problem faced by the Customer

\begin{tabular}{|l|l|l|l|l|}
\hline \multicolumn{2}{|c|}{ Problem faced } & Frequency & Percent & $\begin{array}{l}\text { Cumulative } \\
\text { Percent }\end{array}$ \\
\hline \multirow{4}{*}{$\begin{array}{l}\text { Vali } \\
\text { d }\end{array}$} & $\begin{array}{l}\text { ATM } \\
\text { working }\end{array}$ & 33 & 22.0 & 22.0 \\
\cline { 2 - 5 } & Card get locked & 36 & 24.0 & 46.0 \\
\cline { 2 - 5 } & $\begin{array}{l}\text { Limit on Daily } \\
\text { Usage }\end{array}$ & 32 & 21.3 & 67.3 \\
\cline { 2 - 5 } & $\begin{array}{l}\text { ATM working } \\
\text { slow }\end{array}$ & 12 & 8.0 & 75.3 \\
\cline { 2 - 5 } & $\begin{array}{l}\text { Inability to take } \\
\text { print slip }\end{array}$ & 14 & 9.3 & 84.7 \\
\hline Out of Cash & 23 & 15.3 & 100.0 \\
\cline { 2 - 5 } & Total & 150 & 100.0 & \\
\hline
\end{tabular}

Source : Primary data

From the above table 4,Majority of $24 \%$ of respondent facing problem related to "card get locked",22\% of the respondent facing problem related to "ATM not working",21.3\% of the respondent facing problem related to "limit on daily usage" , $15.3 \%$ of the respondent facing problem related to "out of cash", $9.3 \%$ of respondent facing problem related to "Inability to take print slip" and $8 \%$ of respondent facing problem related to "ATM working slow".

Table 5: Level of Customer Satisfaction towards Gender

\begin{tabular}{|c|c|c|c|c|c|}
\hline & \multicolumn{4}{|c|}{$\begin{array}{l}\text { Level of Customer Satisfaction towards } \\
\text { Gender }\end{array}$} \\
\hline & & $\begin{array}{l}\text { Highly } \\
\text { satisfied }\end{array}$ & Satisfied & Neutral & $\begin{array}{l}\text { Highly } \\
\text { dissatisfi } \\
\text { ed }\end{array}$ \\
\hline \multirow[t]{2}{*}{ Gender } & Male & 31 & 37 & 8 & 3 \\
\hline & Female & 29 & 33 & 6 & 3 \\
\hline
\end{tabular}


International Journal of Engineering Applied Sciences and Technology, 2019

Vol. 4, Issue 4, ISSN No. 2455-2143, Pages 286-290

Published Online August 2019 in IJEAST (http://www.ijeast.com)

\begin{tabular}{|l|l|l|l|l|}
\hline Total & 60 & 70 & 14 & 6 \\
\hline
\end{tabular}

Source Primary data

From the above table 5, Among 150 respondents, majority of 70 respondents are satisfied and 60 respondents are highly satisfied with ATM services in Delhi NCR.

C. Chi-Square Tests Association between Gender and Level of customer satisfaction towards ATM services in Delhi

\section{Hypothesis framed}

H0: There is no significance between gender and Customer satisfaction towards ATM services.

H1: There is significance between gender and Customer satisfaction towards ATM services.

Table 6: Association between Gender and Level of customer satisfaction towards ATM services in Delhi

\begin{tabular}{|l|l|l|l|}
\hline Chi-Square Tests & Value & df & $\begin{array}{l}\text { Asymptotic } \\
\text { Significance (2- } \\
\text { sided) }\end{array}$ \\
\hline Pearson Chi-Square & $.155^{\mathrm{a}}$ & 3 & .985 \\
\hline Likelihood Ratio & .155 & 3 & .984 \\
\hline $\begin{array}{l}\text { Linear-by-Linear } \\
\text { Association }\end{array}$ & .018 & 1 & .893 \\
\hline N of Valid Cases & 150 & & \\
\hline $\begin{array}{l}\text { a. 2 cells (25.0\%) have expected count less than 5. The } \\
\text { minimum expected count is 2.84. }\end{array}$ \\
\hline
\end{tabular}

Since the p-value is greater than our chosen significance level $(\alpha=0.05)$, we do not reject the null hypothesis. We conclude that there is no association between gender and Customer satisfaction towards ATM services in Delhi NCR. Since the calculated value (Pearson Chi - square value) of .155 is lesser than the table value of 7.82 ; we accepted the null hypothesis at a 0.05 significance level.

D. Chi-Square Tests Association between Usage and Level of customer satisfaction towards ATM services in Delhi

\section{Hypothesis framed}

H0: There is no significance between usage pattern and Customer satisfaction towards ATM services.

H2: There is significance between usage pattern and Customer satisfaction towards ATM services.

Table 7: Association between Usage and Level of customer satisfaction towards ATM services in Delhi

\begin{tabular}{|l|l|l|l|}
\hline Chi-Square Tests & Value & df & $\begin{array}{l}\text { Asymptotic } \\
\text { Significance (2- } \\
\text { sided) }\end{array}$ \\
\hline Pearson Chi-Square & $4^{-095}$ & 9 & .905 \\
\hline
\end{tabular}

\begin{tabular}{|l|l|l|l|}
\hline Likelihood Ratio & 5.680 & 9 & .771 \\
\hline $\begin{array}{l}\text { Linear-by-Linear } \\
\text { Association }\end{array}$ & .118 & 1 & .732 \\
\hline N of Valid Cases & 150 & & \\
\hline a. 8 cells (50.0\%) have expected count less than 5. The \\
minimum expected count is .68. \\
\hline
\end{tabular}

Since the p-value is greater than our chosen significance level $(\alpha=0.05)$, we do not reject the null hypothesis. We conclude that there is no association between usage and Customer satisfaction towards ATM services in Delhi NCR.

Since the calculated value (Pearson Chi - square value) of 4.095 is lesser than the table value of 16.92 ; we accepted the null hypothesis at a 0.05 significance level.

E. Chi-Square Tests Association between Education and Level of customer satisfaction towards ATM services in Delhi.

\section{Hypothesis framed}

H0: There is no significance between Education and Customer satisfaction towards ATM services.

H3: There is significance between Education and Customer satisfaction towards ATM services.

Table 8: Association between Education and Level of customer satisfaction towards ATM services in Delhi

\begin{tabular}{|l|l|l|l|}
\hline Chi-Square & Value & df & $\begin{array}{l}\text { Asymptotic } \\
\text { Significance (2-sided) }\end{array}$ \\
\hline Pearson Chi-Square & $15.010^{\mathrm{a}}$ & 9 & .091 \\
\hline Likelihood Ratio & 16.948 & 9 & .050 \\
\hline $\begin{array}{l}\text { Linear-by-Linear } \\
\text { Association }\end{array}$ & 1.535 & 1 & .215 \\
\hline \begin{tabular}{l} 
N of Valid Cases \\
\hline $\begin{array}{l}\text { a. 8 cells (50.0\%) have expected count less than 5. The } \\
\text { minimum expected count is .64. }\end{array}$
\end{tabular} \\
\hline
\end{tabular}

Since the p-value is greater than our chosen significance level $(\alpha=0.05)$, we do not reject the null hypothesis. We conclude that there is no association between education and Customer satisfaction towards ATM services in Delhi NCR.

Since the calculated value (Pearson Chi - square value) of 15.01 is lesser than the table value of 16.92 ; we accepted the null hypothesis at a 0.05 significance level.

\section{CONCLUSION}

In this study 150 responses were involved in the customer satisfaction survey for ATM services in 
Delhi NCR. The customers are highly satisfied with the ATM services in Delhi NCR. Majority of $24 \%$ of respondent facing problem related to "card get locked", $22 \%$ of the respondent facing problem related to "ATM not working",21.3\% of the respondent facing problem related to "limit on daily usage" ,15.3\% of the respondent facing problem related to "out of cash", $9.3 \%$ of respondent facing problem related to "Inability to take print slip" and $8 \%$ of respondent facing problem related to "ATM working slow". The results supported the research hypothesis that Customer Satisfaction towards ATM services has no relation between gender, usage and education of the Customer in Delhi. The banks should pay more attention towards customer problems related to ATM services.

\section{REFERENCE}

1) Agbor, J. M. "Relationship between Customer Satisfaction and Service Quality: a study of three Service sectors in Umea”. Umea School of Business, pp.12-15, 2011.

2) Anderson, E., \& Sullivan, M., "The antecedents and consequences of customer's satisfaction for firms". Marketing Science, 12(2), pp.125-143, 1993.

3) Asif-Khan M., "An Empirical Study of ATM Service Quality and Customer Satisfaction in Pakistani Bank.", European journal of social sciences, 13(3), pp.333-344,2010.

4) Banker, R.D. and Kauffman, R.J. "Strategic contributions of information technology: An empirical study of ATM networks", Proceedings of the ninth International Conference for Information Systems, Minneapolis, MW, 1988.

5) Bhaskar, P.V., " Customer Service in Banks", IBA Bulletin, Vol. XXVI, No. 8 (August), pp. 9-13, 2004.

6) Gustafsson, A., Johnson, M. and Roos.,"The Effects of Customer Satisfaction, Relationship Commitment Dimensions, and Triggers on Customer Retention". Journal of Marketing, 69(4), pp.210-218. ,2005.

7) Kanika Verma, "Measuring Customer Satisfaction towards ATM Services - A Comparative Study of Union Bank of India and Yes Bank", Abhinav National Monthly Refereed Journal of Research in Commerce \& Management, Volume 3, Issue 7, July, pp 3338, 2014.

8) Komal, S.S., "Impact of ATM on customer satisfaction (A comparative study of SBI, ICICI and HDFC banks)",Business
Intelligence Journal Vol. 2(2) (pp.276-287), 2009.

9) Leena Jenefa , “Customer Delight-A Milestone For The Banks", International Journal of Business Management Insight \& Transformations, Vol. 2, Issue 1, pp. 58,2018 .

10) Leon.G., Schiffman, Lesliflazar Kanuk, “ Consumer Behaviour", Pearson Education Seventh Edition, 2004.

11) Sipatonyana L.,Leena Jenefa , "Insights Of Elite Customer: User's Perspective Towards Online Banking" ,International Journal of Recent Advances in Information Technology \& Management, Vol. 2, Issue 2 ,pp. 1-5,2018.

12) Memoria. C.B \& Dr. Memoria. S., Marketing "Kanagement "Kidoh Mahal Allahabad, 2006.

13) Motwani D.and shrimali D. "Consumer adoption and satisfaction towards ATM servies: a comparative study of Udaipur city", International journal of research: paripex, Vol.1, Issue-12,pp.12-13, December 2012.

14) Mukherjee, A. and Nath, P., "Role of electronic trust in online retailing: a reexamination of the commitment-trust theory", European Journal of Marketing, Vol. 41 No. 9, pp. 1173-1202,2007.

15) Oliver Richard L, Rust Roland T Varki Sajeev, "Customer Delight: Foundations, Findings and Managerial Insight", Journal of Retailing, Volume 73(3),pp.311-336, 1997.

16) Philip Kotler, Principles of Marketing, New Delhi, Prentice Hall of India Pvt. Ltd.,p. 143,1996.

17) Dr. V. Premavathy, “ Banking Theory Law and Practice, Sri Vishnu Publication Chennai, p. 150,2007 .

18) Premlatha and Sharma, "A Study of the factors affecting Customers Satisfaction for ATM Services in Vellore District", International Journal Of Marketing, Financial Services and Management Research vol. 1 no.3 .,pp. 114121, 2012.

19) Seethalakshmi \&Dr. P. Kavitha , "Customer Satisfaction in ATM Services: a Study with the Reference to Indian Bank at Tiruchirappalli Corporation", International Journal of Management Focus, April - June, pp. 1-9,2013.

20) Schiffman, L. G. and LazarKanuk, L., Consumer Behaviour. 8th edition. New Jersey Pearson Education Inc, Upper Saddle River Titus, 2004. 
21) Stephen F. King en Juhn-Shiuan Liou, "A framework for internet channel evaluation", International Journal of Information \& Management, March, 24,2004.

22) Taylor, S.A and Baker, T.L., "An assessment of the relationship between service quality and customer satisfaction in the formation of consumer's purchase intentions", Journal of Retailing, Vol.70 No.2, pp.163-78,2000.

23) V. Zeithaml, "Service Quality, Profitability and Economic worth of customers: what we know and what we need to learn", Academy of Marketing Journal, Winter,2000.

24) V.A. Zeithaml, L.L. Berry, \& A. Parasuraman, "The Behavioral Consequences of Service Quality”, Journal of Marketing, Vol. 60 No. 2, pp. 31-46, 1996.

\section{ACKNOWLEDGEMENT}

The authors are thankful to the review committee for their valuable comments and criticism to improve this paper 